Ming $\mathrm{Hu}$ and Chao Guo*

\title{
Fundraising Policy Reform and its Impact on Nonprofits in China: A View from the Trenches
}

DOI 10.1515/npf-2016-0003

\begin{abstract}
After decades of strict charitable solicitation regulation, the Chinese government has recently begun to experiment with fundraising policy reforms in some local jurisdictions. In this comparative study of two metropolitan cities, Shanghai and Guangzhou, we examine the nature, content, and scope of the reform and its impact on nonprofit organizations. Our archival analysis indicates that the new policies in both cities helped create a more supportive regulatory environment for the nonprofit sector, though they differed in the extent to which policy change departed from the status quo. Yet somewhat surprisingly, the reform elicited a lukewarm reaction from the nonprofit sector: only a very small fraction of nonprofit organizations actually fundraised under the new policies, and their performance varied remarkably. Our field work further reveals that many nonprofit leaders had reservations about the policy initiatives. Possible reasons for such reservations include fragmented policies on nonprofit registration and taxation, discretionary authorization system, and the weak fundraising capacity of nonprofits.
\end{abstract}

Keywords: nonprofit organization, nongovernmental organization, charitable solicitation, fundraising policy, China

\section{Introduction}

Public fundraising is widely seen as a natural right of charitable organizations. Such a right nevertheless is severely constrained in many authoritarian states where charities are regarded as a potential challenge against state power and repressed by the government (Clark 1995; Clarke 1998; Fisher 1998). For most organizations operating in China's nonprofit sector today - over 600,000

\footnotetext{
*Corresponding author: Chao Guo, School of Social Policy \& Practice, University of Pennsylvania, PA, USA, E-mail: chaoguo@sp2.upenn.edu

Ming Hu, School of Human Ecology, University of Wisconsin, Madison, WI, USA, E-mail: mhu37@wisc.edu
} 
registered and millions unregistered, ${ }^{1}$ the strict charitable solicitation regulation set by the government remains an important roadblock to their growth. From the rebirth of the nonprofit sector in the 1980s until the recent past, only a small number of public fundraising foundations and government-affiliated nonprofit organizations had been allowed to raise funds from the public. Most Chinese nonprofits thus were forced to turn to government subsidies, foreign funds, and earned income to finance their operations and activities.

This situation, however, shows some signs of change as several local jurisdictions, with blessings from the Ministry of Civil Affairs, have recently begun to experiment with opening the public fundraising market for charitable organizations. The relaxation of solicitation regulation represents a tangible change in public policy that has important implications for China's nonprofit sector. What did these local reforms look like in practice? How did these reforms change the motivations and behaviors of nonprofit organizations? Given that the China's first charity law was passed in March 2016 but remains ineffective until September 2016, ${ }^{2}$ understanding the effects of local policy initiatives on nonprofit behaviors is critical in at least two aspects. First, it will help evaluate the efficacy of the policies at various local jurisdictions. Second, it will provide insights for implementing of the newly-born charity law in order to build a more benign institutional environment for Chinese nonprofits.

This study aims to examine the depth and scope of fundraising policy reforms in two local jurisdictions - cities of Shanghai and Guangzhou, explore the responses of a wide range of nonprofits to these local reforms, and identify the various factors that might have led to such responses. Drawing upon archival data and field work, we find qualitative differences between the policy initiatives of the two cities. Despite the differences, the policy reforms from both cities represented a useful step toward a more supportive regulatory environment for Chinese nonprofits. Yet on the other hand, we find that nonprofit organizations did not unanimously welcome the loosening of fundraising regulation that was supposed to greatly alleviate their financial hardship. In particular, our interviews revealed three types of reactions to the new fundraising policy: welcome, indifference, and challenge. We further consider several factors that might have shaped the reactions of nonprofit organizations.

\footnotetext{
1 The Ministry of Civil Affairs (2015) estimated that there were 606,000 officially registered nonprofits of all types in 2014. According to Guo, Xu, Smith, and Zhang (2012), the estimate of unregistered grassroots organizations ranged from 8 to 10 million.

2 See the PRC Charity Law, accessed May 1, 2016 (http://www.npc.gov.cn/npc/lfzt/rlyw/node_ 28594.htm). It is noteworthy that the local policies will have to be changed to be consistent with the national charity law, but the timetable for revision remains unknown.
} 


\section{Challenges of the Fundraising Regulation}

Philanthropy as "voluntary action for the public good" (Payton 1988) has existed in each major culture since early civilizations (Robbins 2006). The emergence of modern states led to the unprecedented encroachment of government power into private spheres, including charitable activities and organizations (Hall 2006). In democratic regimes, nonprofit organizations as an important part of voluntary associations are usually protected by the state and so is charitable solicitation. Also, charitable solicitation itself may involve free speech interest and thus is assured by the government as in the United States (Ogburn 1989). A variety of laws and policies are made to offer tax deduction or exemption benefits to donors and collectors in order to foster charitable contributions (see Simon, Dale, and Chisolm 2006). Within this context, the state regulates charitable fundraising primarily for the following three purposes: eliminating frauds like bogus fundraising or charity embezzlement, reducing charitable inefficiency to ensure that the greatest percentage of fundraising proceeds is used for charitable purposes, and empowering donors to choose reliable charities (Breen 2009). As a result, nonprofit organizations are entitled to charitable solicitation, though registration for solicitation is still required unless under certain settings of exemption. ${ }^{3}$

However, autocratic and authoritarian states often consider voluntary associations, even charities, as a natural threat to state power and repress them harshly by setting demanding registration standards, developing complicated tax rules, and allowing government discretion over nonprofit organizations (Clarke 1998; Dirusso 2011; International Center for NPO Law 2011). One effective strategy is to control nonprofit organizations' funding sources so as to weaken their capacity. For example, many regimes, including such quasi-democracies as Russia, Ethiopia, Afghanistan, and Zimbabwe that are known to be unfriendly toward civil society, restricted or prohibited domestic nonprofit organizations from receiving foreign donations (Johnson 2011). But it remains unclear how they regulate nonprofit organizations' fundraising activities at home as relevant literature is in scarcity.

Charities and other types of voluntary associations were totally banned in China in its communist era between the 1950s and 1970s as the government declared charity as "a camouflage the ruling class uses to conceive and

3 Such settings vary across states. For example, Wisconsin State Legislature stipulates that some nonprofit organizations are exempt from solicitation registration, such as organizations that solicit only their members, organizations that tend to solicit contribution less than a minimum amount, and organizations that are private schools, etc. See https://docs.legis.wis consin.gov/statutes/statutes/202/II/11. 
narcotize the people" (Dong 1950). After its Opening-Up and Reform of the 1980s, the state allowed the establishment of three types of nonprofit organizations: foundations (including public and nonpublic fundraising foundations), social associations (shetuans) and private non-enterprise units (minfeis). A public fundraising foundation (gongmu jijinhui) is eligible to fundraise from the general public but must spend no less than $70 \%$ of the previous year's income. A nonpublic fundraising foundation is ineligible to fundraise from the general public and must spend no less than $8 \%$ of the surplus from the previous year. ${ }^{4}$ A social association is a membership-based nonprofit organization that is established for members' shared interests. ${ }^{5}$ And a private non-enterprise unit is not membership-based, established to provide not-for-profit social services. ${ }^{6}$ Although all four types of nonprofits operated as legal person and receive donation from various individuals and entities, only the public fundraising foundation were allowed to seek contributions from the general public. ${ }^{7}$ In addition, a number of restrictions were used to control the growth of nonprofit organizations. The measures included a dual-control system where nonprofits are required not only to register with MCA or its local agency (Bureau of Civil Affairs, BCA) but also to be affiliated and supervised by a public agency in its functional area, ${ }^{8}$ unfavorable and inconsistent taxation rules, irregular monitoring and punishment, and prohibition of charitable solicitation (Guo and Zhang 2013; Jia 2003; Lee 2009).

Though public fundraising foundations are allowed to perform charitable solicitation, most of which are actually established by and affiliated with the government. Moreover, state-affiliated political institutions (quntuan zuzhi) such

4 Refer to Article 2 and 29 of the Regulations on the Management of Foundations, accessed May 10, 2015 (http://www.cecc.gov/resources/legal-provisions/regulations-on-the-management-offoundations-chinese-text).

5 Refer to Article 2 of the Regulations on the Registration and Management of Social Associations, accessed May 10, 2015 (http://www.chinacharityfederation.org/WebSite/NewsShow/66/1119).

6 Refer to Article 2 of the Regulations of Registration and Management of Private Non-Enterprise Units, accessed May 10, 2015 (http://news.xinhuanet.com/ziliao/2005-10/17/content_3625623.htm). According to the newly promulgated Charity Law of 2016, minfeis may be called "social service organizations," which nevertheless needs to be confirmed by implementation rules that are under development.

7 The new Charity Law stipulates that all "charitable organizations," which can take the form of foundation, shetuan, or social service organization, can apply for solicitation eligibility. However, the law does not specify whether nonpublic fundraising foundations can apply to be charitable organization. See Article 8 and 23.

8 The new law has abolished this dual-control registration requirement for "charitable organizations," but how previously registered nonprofits should be incorporated into the new administration system remains unclear. 
as the Communist Youth League and government-affiliated nonprofit organizations like the China Charity Federation (CFC) and Red Cross Society of China (RCSC) were also granted the right to solicit contributions from the public. Government agencies, primarily BCA, were also engaged in collecting private donations. ${ }^{9}$ In contrast, only with special permission from the government were independent nonprofits allowed for solicitation. This restriction resulted in the heavy dependence of these organizations on foreign aids, most of which, however, was channeled into governmentaffiliated institutions (see Spires 2011). However, the decrease of foreign donations in recent years owing to stricter foreign exchange regulations and international aid agencies' withdrawal from China have caused serious financial difficulties specifically among grassroots nonprofit organizations (Lan 2012). As a consequence, grassroots nonprofits now have to turn to government contracting which has grown rapidly in recent years (Zhao 2013), though they are increasingly concerned about the loss of independence from the state.

Fundraising monopoly by a few entitled nonprofit organizations and government agencies caused limited fundraising incentives, lack of transparency and efficiency in fundraising management, and loss of private donations owing to the public's low trust in nonprofit organizations. For example, during the 2011 Guo Meimei Incident, a set of photos displaying the lavish life of a young woman who claimed to be the CEO of a RCSC-affiliated organization went viral online. These photos received a multitude of vehement criticisms against the RCSC for its misuse of private contributions and costed it a significant loss of donations, though the woman later revealed she was not directly affiliated with the RCSC (Xu 2011).

Since 2010, in order to foster local philanthropic causes and encourage private donations, nine provincial and municipal governments have developed policy initiatives aiming at extending solicitation eligibility from public fundraising foundations and government-affiliated institutions to other types of public and nonprofit organizations, including minfeis, shetuans, and public service units. ${ }^{10}$ Prior to these local reforms, China had no law or government ordinance that clearly stated how charitable solicitation should be performed, even for public fundraising foundations and government-affiliated associations that were

9 The Charity Law Article 30 stipulates that the government should build coordination mechanisms, provide information, and guide fundraising action in response to major emergencies and risks. But the new law does not specify how to incorporate various state-related nonprofits into the new nonprofit management system.

10 Public service units are public agencies that are established and run directly by the government to assist in managing public services and goods, though legally separate from the government. 
eligible for solicitation; with introduction of the new fundraising policies, fundraisers for the first time have clear instructions on what to do "before, during, and after solicitation" (Breen 2009).

However, research on this wave of fundraising policy reforms is virtually non-existent. How were these policy initiatives similar or different across local jurisdictions? To what extent did these reforms lift the restrictions on philanthropic solicitations and thereby contribute to a more supportive regulatory environment for China's nonprofit sector? And how did local nonprofits react to the reforms? This study attempts to answer these questions.

\section{Methods \& Data}

We collected our data from archives and semi-structured interviews. We started with the collection of archival data, including relevant government documents in all nine jurisdictions that promulgated the new fundraising policy, and media coverage on the specific policy initiatives. Between 2010 and 2015, five provinces or province-equivalent jurisdictions (including Jiangsu, Hunan, Ningxia, Beijing, and Shanghai) and four cities (including Ningbo, Changsha, Guangzhou, and Shantou) had promulgated local policies on charitable solicitation. In addition, another two provinces, Yunnan and Shanxi, and one city, Shenzhen, had submitted their draft policies to local congresses for review and approval.

After some preliminary analysis of the archival data, we selected two cities-Shanghai and Guangzhou--for an in-depth comparative research on how their nonprofit organizations responded to these policy reforms. There are several reasons why the two cities are reasonably good candidates for comparison. First, the new policy in Shanghai and Guangzhou represented the two ends of the policy change spectrum, cautious relaxation and aggressive relaxation, thereby providing us a great amount of variations across regions. Second, the new policy in both cities was released around the same time, leaving out the time-related factors that could affect nonprofits' responses to such a policy change. Third, both cities were wellknown for their competent governments, which ensure their administrative capacity to implement the new policy and thus help alleviate possible bias due to poor policy implementation. Finally, among China's largest metropolitan areas, both cities had an adequate population of active nonprofit organizations, providing us a large pool to sample research participants.

Our main information source is based on the official websites of local nonprofit administrations, respectively the Guangzhou BCA [http://gzcs.gzmz.gov.cn/csxxw] and Shanghai BCA [http://www.shmjxx.org/], where we collected information of 
fundraising organizations and type and time of fundraising events. However, data on fundraising performance remained inaccessible.

In order to gather nonprofit practitioners' perspectives on the scope and impact of these policy reforms, we collected interview data from May to July in 2014 and from June to August in 2015. We first created a list of active nonprofit organizations with assistance from some local nonprofit leaders. We then sent an interview invitation to the leader of each organization on the list. The leaders from a total of 30 nonprofit organizations participated in the interview, including 14 from Shanghai and 16 from Guangzhou. They came from all types of nonprofit organizations: public fundraising foundations, private fundraising foundations, shetuans, minfeis, public service units, and unregistered nonprofits (see the Appendix for more information about these organizations). The interviews were conducted face-to-face or via telephone and lasted 40-60 minutes each. The interviewer took notes during the interview and transcribed the notes into text thereafter.

Interview notes were open coded to identify key concepts and categories across respondents (Strauss \& Corbin 1990). We made repetitive comparison between interview data and archival data to track consistency and inconsistency in order to understand the connections between nonprofit-related laws and policies, new fundraising policies, and fundraising behaviors among nonprofit organizations.

\section{Findings}

In this section, we first compare the main characteristics of the new fundraising policies in Guangzhou and Shanghai, followed by an examination of solicitation practices and performance in local nonprofits after the new policies were promulgated. We then report interview data about the reactions of local nonprofits to the new policies. Finally, we identify a number of factors that might have shaped the responses of these organizations.

\section{The New Fundraising Policy in Guangzhou and Shanghai}

Table 1 compares the main characteristics of the new fundraising policies in both cities.

The overarching message delivered in Table 1 is that the new fundraising policies established a multi-tiered authorization system that offers varied levels 
Table 1: Characteristics of the new fundraising policy in Guangzhou \& Shanghai.

\begin{tabular}{|c|c|c|}
\hline & Guangzhou & Shanghai \\
\hline Name of the Policy & $\begin{array}{l}\text { The Guangzhou Charitable } \\
\text { Solicitation Regulations }\end{array}$ & $\begin{array}{l}\text { The Shanghai Charitable } \\
\text { Solicitation Regulations }\end{array}$ \\
\hline Effective & May, 2012 & September, 2012 \\
\hline Defining charity & $\begin{array}{l}\text { elderly care, aid for the } \\
\text { disabled and orphan, poverty } \\
\text { reduction, disaster relief, etc. }\end{array}$ & $\begin{array}{l}\text { suffering relief, education, } \\
\text { science and technology, culture, } \\
\text { sports, environment, social } \\
\text { welfare, etc. }\end{array}$ \\
\hline $\begin{array}{l}\text { Eligibility expansion } \\
\text { beyond public } \\
\text { fundraising foundations }\end{array}$ & $\begin{array}{l}\text { minfeis, shetuans, and public } \\
\text { service units }\end{array}$ & Only shetuans \\
\hline Licensing type & permission (shenpi) ${ }^{\mathrm{a}}$ & reporting (beian) \\
\hline License application & $\begin{array}{l}20 \text { days before a solicitation } \\
\text { event }\end{array}$ & $\begin{array}{l}10 \text { days before a solicitation } \\
\text { event }\end{array}$ \\
\hline Validity of license & 3 months & 12 months \\
\hline Information disclosure & $\begin{array}{l}\text { Within } 15 \text { days after the end of } \\
\text { a solicitation event }\end{array}$ & $\begin{array}{l}\text { Within } 45 \text { days after the end of } \\
\text { a solicitation event }\end{array}$ \\
\hline$\%$ of fundraising cost & $\begin{array}{l}\text { Fundraising cost should not } \\
\text { exceed } 20 \% \text { of the funds } \\
\text { collected. }\end{array}$ & Unspecified \\
\hline Use of funds collected & Unspecified & $\begin{array}{l}\text { A nonprofit should spend no } \\
\text { less than } 70 \% \text { of its funds } \\
\text { collected in the previous year. }\end{array}$ \\
\hline $\begin{array}{l}\text { Eligibility of the } \\
\text { government }\end{array}$ & $\begin{array}{l}\text { The government can require } \\
\text { eligible organizations to } \\
\text { perform solicitation under } \\
\text { emergencies and also can } \\
\text { supervise nonprofit } \\
\text { fundraising. }\end{array}$ & Unspecified \\
\hline
\end{tabular}

${ }^{\mathrm{a}}$ The RCSC branches, public fundraising foundations, and the CFC branches just needed to practice "reporting" procedures since they were eligible for public solicitation before the release of the new policy.

of privileges and restrictions to different types of nonprofits. First of all, the new policy did not change the local governments' solicitation privilege. Shanghai's policy did not specify whether the government was eligible for solicitation, but the local government organized solicitation events before the promulgation of the new policy. In Guangzhou, Article 13 of the Guangzhou Charitable Solicitation Regulations (Guangzhou Congress 2012) clearly states that " $(\mathrm{t})$ he municipal and district governments can mobilize eligible organizations to solicit contributions when natural disasters or other serious emergencies and 
risks occur." In addition, public service units in Guangzhou, which acted as government agencies, were allowed to solicit.

Second, many government-affiliated nonprofit organizations received privileges under the new policies. In Guangzhou, the RCSC, the CCF, and public fundraising foundations did not need special permission before conducting solicitation. They instead are required to "conduct [solicitation] by following the mission, work areas, and places stipulated in their bylaws and report to the BCA" (see Article 5). In Shanghai, the new policy states that "the RCSC and public fundraising foundations should follow what were stipulated in previous laws and ordinances” (see Shanghai Congress 2012, Article 4) and thus exempts them from the new regulation.

Third, different levels of authorization were extended to the four types of regular nonprofit organizations. It remained the same in both cities that nonpublic fundraising foundations were not allowed to solicit contributions. In Shanghai, besides public fundraising foundations, only shetuans were eligible for solicitation. Nevertheless, like public fundraising foundations, most shetuans were also government-affiliated; only one shetuan was independent from the government as we were told by nonprofit leaders during our fieldwork in Shanghai. In Guangzhou, both shetuans and minfeis were authorized to solicit under the new policy. Table 2 presents solicitation eligibility changes before and after the new fundraising policies.

Table 2: Solicitation eligibility before and after the new fundraising policy.

\begin{tabular}{|c|c|c|c|c|}
\hline & \multicolumn{2}{|l|}{ Guangzhou } & \multicolumn{2}{|l|}{ Shanghai } \\
\hline & Before & After & Before & After \\
\hline The government (e. g. BCA) & Yes & $\begin{array}{l}\text { Allowed to "mobilize" } \\
\text { eligible organizations }\end{array}$ & Yes & Unspecified \\
\hline Public service units & Unspecified & Yes & Unspecified & Unspecified \\
\hline RCSC \& CCF & Yes & Yes & Yes & Yes \\
\hline $\begin{array}{l}\text { Public fundraising } \\
\text { foundations }\end{array}$ & Yes & Yes & Yes & Yes \\
\hline $\begin{array}{l}\text { Nonpublic } \\
\text { fundraisingfoundations }\end{array}$ & No & No & No & No \\
\hline Shetuans & No & Yes & No & Yes \\
\hline minfeis & No & Yes & No & No \\
\hline
\end{tabular}

In principle, permission (shenpi) as a form of licensing is considered to be more strict than reporting (bei-an); in practice, they worked almost the same way. In the shenpi system, a soliciting organization was required to apply for a license from BCA 
ahead of schedule and the latter would inform of its decision within 20 days. In other words, the soliciting organization needed to apply at least 20 days prior to a fundraising event. In the beian system, the soliciting organization ought to report to BCA 10 days before the fundraising event, and BCA would check the materials submitted and may stop the fundraising plan if they disagreed with it (this "checking" function was not clearly stated in the policy document though). In this sense, we may argue that there was no critical difference between shenpi and beian.

There were high rates of approval for fundraising plans in both systems. In Guangzhou, more than $95 \%$ of applications received approval. As a nonprofit leader said,

The approval rate is very high and thus shenpi is almost the same as beian. With a small staff, BCA has no time to examine the details of each application (and tends to approve it if no apparent problems are spotted).

In Shanghai, we heard no beian case being stopped by BCA. Perhaps one important reason is that all fundraising events were organized by public fundraising foundations that had been eligible for solicitation even before the passage of the new policy.

\section{Nonprofits' Fundraising Participation and Performance}

Table 3 shows the total number of nonprofits that organized at least one solicitation event in the two and half years after the passage of the new policies. While public fundraising foundations in Guangzhou and Shanghai remained eligible, nonpublic fundraising foundations were excluded from the policies and did not launch any fundraising events. In Guangzhou, 96 of 3,616 minfeis and 29 of 2,862 shetuans were licensed to perform charitable solicitation. 31 public fundraising foundations also participated in solicitation, accounting for $47 \%$ of the population. Moreover, a few public service units solicited. In Shanghai, only a few public fundraising foundations registered to conduct solicitation. None of the shetuans registered to solicit, though they became eligible under the new policies. Apparently, only a small fraction of nonprofits that became eligible under the new policies actually registered for fundraising events.

Because complete data of solicitation performance were inaccessible on the BCAs' websites, we turned to interview data to explore the nonprofits' solicitation efforts and performance. Among the 17 nonprofit organizations in Guangzhou, 10 reported that they were engaged in solicitation. Their performance varied greatly. A shetuan raised RMB 17 million (equivalent to \$2.62 million with an exchange ratio of $6.5: 1)$, almost all through fundraising events. Most 
Table 3: Organizations receiving solicitation licenses under new fundraising policies in Guangzhou and Shanghai.

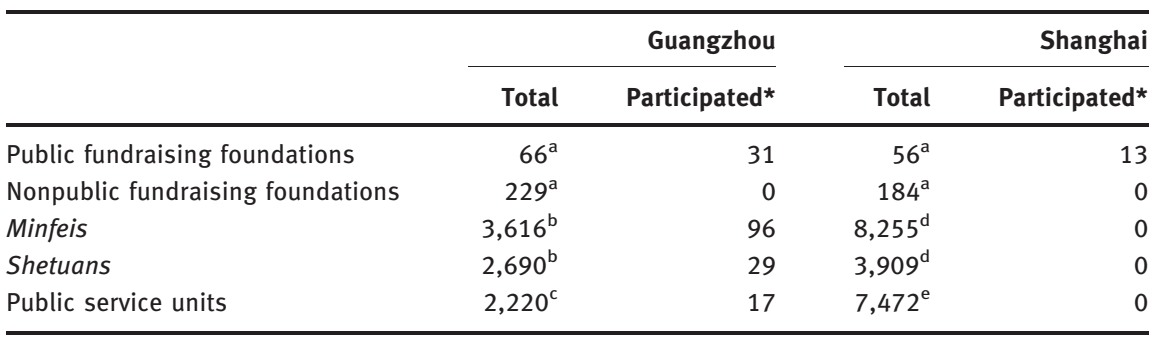

*The data were updated in December, 2015

${ }^{\mathrm{a} D}$ Data source: China Foundation Center. http://www.foundationcenter.org.cn

${ }^{\text {b }}$ See Li (2014)

${ }^{\mathrm{C}}$ Data source: Guangdong Public Service Units Information Center [guangdong shiye danwei dengji guanliwang] http://www.gdsy.gov.cn

${ }^{\mathrm{d} D a t a}$ source: Shanghai Social Organization Wang [Shanghai shehui zuzhi wang]

http://stj.sh.gov.cn

${ }^{e}$ Data source: Shanghai Public Service Unite Administration [shanghai shiye danwei dengji guanli] http://www.sydjsh.cn

nonprofits raised a small amount of funds through solicitation, ranging from thousands to tens of thousands of RMB. One public service unit even reported zero contribution in a fundraising event. The only public fundraising foundation we interviewed raised RMB 30 million in solicitation, accounting for only $1.5 \%$ of its total annual revenues.

Among the Shanghai cases, the three public fundraising foundations raised a considerable amount of contributions from solicitation events, ranging from RMB 5 million to RMB 18 million and accounting for over 30\% of their annual revenues. The two minfeis, which remained ineligible after the new policy, performed solicitation indirectly, but they received only a very small amount of donations.

Overall, our analysis shows only a small fraction of nonprofit organizations fundraised under the new policies. However, it should be noted that, due to the lack of comparative data on nonprofit organizations' fundraising engagement before the new policies were passed, it is impossible to verify whether the number of nonprofits that performed solicitation increased or not. For the same reason, nor is it clearly known whether nonprofits collected more or less funds in their solicitations under the new policies, though the assumption of more contributions are very plausible given the loosening, at least not tightening, of fundraising regulations for all types of nonprofits. Also, our fieldwork did not find any exact example of solicitation decrease. 


\section{Nonprofits' Attitudes toward New Fundraising Policies}

To further examine the reactions of local nonprofits to the new policies, we asked a group of nonprofit leaders in semi-structured interviews about what influences they thought the new policies would have on the institutional environment of nonprofit fundraising. The reactions of the interviewees can best be described as lukewarm. The interviewees in general expressed cautious optimism about the influence of the new policies. Among the 17 Guangzhou nonprofit leaders being interviewed, two viewed the influence of the Guangzhou policy as strongly positive, nine as somewhat positive, two as neither positive nor negative, and the remaining three reported they even did not know the existence of the policy. In Shanghai, no interviewees considered the new policy as strongly positive, six considered it as somewhat positive, four as neither positive nor negative, and the remaining four reported "Don't know".

Furthermore, our analysis reveals that nonprofit organizations responded to the new policy with three types of attitudes: welcome, indifference, and challenge.

Welcome. Some nonprofits welcomed the relaxation of solicitation regulation and actively applied for solicitation licenses for their fundraising events. For them, the new policies have three positive effects.

First, some nonprofits that had been ineligible for solicitation were allowed to solicit contributions under the new policies. As a result, their fundraising performance significantly improved. Quoting a minfei CEO in Guangzhou,

Before the new policy, we were ineligible for solicitation. In shortage of funds, we had to conduct solicitations in private and were satisfied with small amounts of contributions, in fear of government punishment. On the other hand, donors usually gave us small gifts, concerned about our illegitimacy in solicitation. Due to the new fundraising policy, we finally can solicit contributions in public and feel confident about our legitimacy. Our revenues have increased by a large margin in the past years.

Second, the new policies developed a set of specific, though still fallible, rules about who can solicit, how solicitation should be conducted, and how to practice accountability. According to our interviewees, these rules were conducive to reducing frauds and unaccountable solicitation behaviors, thereby improving the public's trust in charitable solicitation.

Third, public fundraising foundations also benefited from the new policies. Even though they had been eligible for solicitation according to the Regulations on Management of Foundations of 2004, there was no law or public policy that specified their rights and responsibilities in solicitation. Included in the new policy like other types of nonprofit organizations, public fundraising foundations' eligibility was 
explicitly confirmed in the form of local legislation (Note: the Regulations of 2004 was a government directive).

Indifference. Some nonprofits remained indifferent to the new policy. One important reason was that they were able to gain reliable funding from other sources, including government grants, foundation grants, and large gifts from major corporate or individual donors. Therefore, they gave little attention to solicitation. As a minfei leader claimed,

We focus our efforts on our programs. It is easy to get grants as long as we have high performance in the programs. It is unnecessary to solicit contributions.

Another reason was that some nonprofits believed that there were few chances for them to obtain substantial contributions owing to the lack of donor-attracting projects or lack of fundraising capacity. A leader of a Guangzhou nonprofit that became eligible under the new policy said,

We are dedicated to capacity building and networking for nonprofit organizations. Unlike social service providers in education, poverty alleviation, elderly care and the like, our work may be beyond the understanding of ordinary people. It takes time to develop stewardship among stakeholders before performing solicitation.

A third reason for nonprofits' indifference was the belief among some organizations that the new policies would not affect their fundraising due to the government's limited monitoring capacity. For example, several nonprofit organizations reported that they collected donations through charitable sales, charity concerts, or solicitation within personal networks. Their leaders even were unaware of the new fundraising policies, as found during our interviews. Even after knowing the major policy changes, they planned to continue ignoring them. One nonprofit leader commented,

I don't want to bother to apply for the solicitation license. The procedures are boring and time-consuming given that I just solicit some small gifts. The government cannot notice our fundraising activities.

Challenge. Some nonprofits, especially organizations remaining ineligible, challenged the new fundraising policies. Their leaders argued that solicitation ought to be a natural right of nonprofit organizations and the government has no right to grant eligibility. For example, the head of an unregistered nonprofit in Guangzhou argued,

I perform solicitation every day, ignoring the fundraising policy. I believe that solicitation eligibility should be naturally granted by the fundraising market: Donors are able to decide to whom they give and solicitors follow the law of survival of the fittest. The 
government should take its supervision duty and should not control fundraising eligibility. Once the government is involved in eligibility management, it breeds corruption and power abuse.

These nonprofits fundraised in the gray zone between actively soliciting and passively receiving gifts, and between publicly soliciting and privately asking for donations. Interestingly, some eligible nonprofits also chose to use the same strategy in order to avoid applying for a fundraising license. One example of obscuring actively soliciting and passively receiving gifts was to set up a webpage to promote a project on a nonprofit's website or other social media platforms, or sell a virtuous charitable "product" (e. g. an e-card of RMB 30 to help poor schoolgirls) on an online shopping center to receive donations. In another case, a nonprofit leader described how he played in the gray zone.

I have several WeChat (a social media platform) circles where I knew some people, but of course not everyone. One day I announced in the circles that I would cook at home to treat my visitors a nice dinner. But every visitor was expected to donate at least RMB 100 to my organization. Guess what? In this event we collected RMB 30,000 and therefore overcame a pressing financial problem. Of course we will disclose later how the money would be used in the circles. I used this fundraising strategy twice or more each year and it worked very well.

Eligible nonprofits, especially public fundraising foundations, in some sense supported such challenges by "lending" fundraising eligibility to other nonprofit organizations that are unable or unwilling to apply for a solicitation license. For example, the Shanghai United Foundation has hosted an annual trail walking program since 2011. The program served as a fundraising platform through which participatant nonprofits could legally solicit funds from their potential donors. In 2012, the foundation and other 22 nonprofit organizations together collected RMB 3.4 million from this program.

\section{Major Factors Shaping Nonprofits' Responses}

We have identified several factors that were closely related to nonprofits' responses to the new local policy: fragmented nonprofit policies, discretionary authorization measures, and nonprofits' weak fundraising capacity.

Policy fragmentation. The system for regulating and controlling nonprofit organizations remained fragmented in China (Yu 2006; Lee 2009). In the absence of a general nonprofit law in the past decades, the central government promulgated serval special ordinances (as shown in Footnotes 4-6) to respectively regulate the four types of nonprofit organizations that are not affiliated with the government. For this reason, the government had great discretion over nonprofits. Moreover, what 
was missing is effective coordination between different government departments, particularly the departments in charge of nonprofit registration and general administration, tax collection and deduction, and government contracting. The new fundraising policies, unfortunately, did not change the fragmented system.

First, the continued operation of the fragmented nonprofit registration system directly affected some nonprofits' solicitation eligibility. A group of nonprofits, including the RCSC system, the CCF system, and some mass associations, were actually government-affiliated and thus exempt from registration. ${ }^{11}$ Due to their special registration status, BCA could not effectively supervise their fundraising behaviors. In contrast, other nonprofits were required to officially register with BCA, which proved to be a great challenge if government sponsorship was absent: To complete the registration, a nonprofit would need another organization, usually a governmental department or a government-affiliated entity, to serve as its professional leading unit and take the ultimate responsibility for all its operations. Though this requirement was removed for the nonprofits in four fields (including professional and trade associations, science and technology related nonprofits, charitable organizations, and community-based service nonprofits), it applied to nonprofits in other fields such as policy advocacy and citizenship education (Communist Party of China 2013). The nonprofits in labor rights, women rights, LGBT rights, and other politically sensitive work areas were still faced with great registration barriers due to the least chance in finding a professional leading unit. As a consequence, some remained unregistered (Spires, Tao, and Chan 2014), and some others registered as for-profit enterprises in order to operate as a formal organization, although forprofit registration meant they were ineligible for any tax-exempt benefits. Among the 30 nonprofits being interviewed, three were unregistered, including two LGBT organizations and one organization for anti-discrimination against hepatitis $B$ patients. These unregistered and mis-registered nonprofits were automatically ineligible for solicitation under the new policies.

Second, adverse tax policies and complex tax deduction practices further impeded charitable fundraising. ${ }^{12}$ While BCA was arguably the primary government agency in charge of nonprofit management, it was tax authorities that would determine whether and how much a nonprofit got tax deductions. Nonprofits were subject to two primary types of taxes, business tax and income tax, and the tax rates were the same as those for for-profit enterprises. While

11 The CCF system experienced significant changes in the past years. Some has registered as public fundraising foundations or social associations with local BCAs.

12 The new Charity Law does not involve major policy changes about tax deduction for nonprofits and donors. 
income tax applied to all types of nonprofits, business tax varied. Foundations and a small fraction of minfeis were exempt from business tax, but most minfeis were still required to pay business tax. shetuans were allowed to apply for business tax exemptions only three years after registration; before that they should pay business tax for all revenues but membership dues. While minfeis were not allowed to apply for such exemptions, sometimes the tax authorities would just grant them by using their discretion. It is fair to argue that the high tax rates and nontransparent exemption rules were detrimental both to nonprofits' incentive for fundraising and to donors' willingness of giving. Table 4 shows the tax deduction rules for officially registered nonprofits.

Table 4: Tax deduction rules for nonprofit organizations.

\begin{tabular}{|c|c|c|c|}
\hline & shetuans & minfeis & $\begin{array}{l}\text { Foundations } \\
\text { (Public \& Nonpublic) }\end{array}$ \\
\hline Business tax & $\begin{array}{l}\text { Tax rate } 5.5 \% \text {. Tax } \\
\text { exemption can be } \\
\text { applied only three } \\
\text { years after a } \\
\text { shetuan's } \\
\text { establishment but } \\
\text { will be valid for } 5 \\
\text { years. }\end{array}$ & $\begin{array}{l}\text { Tax rate } 5.5 \% \text {. It can } \\
\text { be deducted due to tax } \\
\text { authorities' discretion } \\
\text { but cannot be applied } \\
\text { for. }\end{array}$ & Unrestrictedly exempt \\
\hline Income tax & Tax rate $25 \%$ & Tax rate $25 \%$ & Tax rate $25 \%$ \\
\hline $\begin{array}{l}\text { Eligibility of } \\
\text { giving donors } \\
\text { tax-deductible } \\
\text { receipts }\end{array}$ & $\begin{array}{l}\text { Special government } \\
\text { permission needed }\end{array}$ & $\begin{array}{l}\text { Unspecified. Some } \\
\text { received special } \\
\text { government permission. }\end{array}$ & $\begin{array}{l}\text { Special government } \\
\text { permission needed. }\end{array}$ \\
\hline
\end{tabular}

Third, it is noteworthy that a nonprofit's tax exemption status was not directly or necessarily associated with the tax exemptions its donors received. To enable its donor, either an individual or an entity, to receive tax deductions from a gift, a nonprofit must be eligible to provide the donor with a tax exemption receipt. This eligibility, however, would be granted only when the three government agencies, the tax authorities, BCA, and the government treasury department, met to create a list of eligible nonprofit organizations. For this reason, very few nonprofits were able to give their donors tax deduction receipts. For example, in 2013 only 24 nonprofits were eligible, among a population of more than 6,000 nonprofit organizations in Guangzhou. Even eligible for issuing tax-deductible 
receipts, a nonprofit could face another challenge: the receipts may not be accepted by the tax authorities of the donor's residence region! As an interviewee commented,

If an enterprise in Hubei donates to a nonprofit in Guangzhou, the Hubei tax authorities are unhappy. This donation means loss of tax revenues if Hubei accepts the validity of the tax-deductible receipt sent from Guangdong!

The situation became paradoxical when fragmented registration systems and tax policies were interwoven. Quoting one nonprofit researcher (NGOCN2015),

\begin{abstract}
Registration as a nonprofit, application for nonprofit tax exemptions, application for donation deductible receipts--each has different requirements, different government departments in charge, and different paper work systems. How many thresholds does a theoretically eligible nonprofit have to meet to be actually tax exempt? ... What does it mean by being a nonprofit that is eligible for solicitation but ineligible for tax exemptions? What does it mean by being a nonprofit that is tax exempt but ineligible for giving donors tax deductible receipts? The current policies cannot yet answer these questions.
\end{abstract}

Discretionary authorization. The discretionary authorization system caused several problems for nonprofit fundraising. First, the government and its affiliated organizations remained eligible in the charitable fundraising market but out of the reach of current regulations, which allows government-related agencies to fundraise but do not specify their responsibilities. Their privilege dampened nonprofits' enthusiasm for the new policies. A nonprofit leader commented in the interview,

There is no significant breakthrough in the current policy, one feature of which is the dominance of numerous government-sponsored organizations. Opening solicitation eligibility makes sense only when the government system stays away from solicitation. For example, CCF and RCSC depend mainly on the government system to "collect donations" while voluntary contributions from solicitations account for a very small fraction.

Another interviewee explained more clearly why the government's privilege was detrimental to nonprofits,

I worked for a public fundraising foundation that was established by the Association of Disabled Persons, actually a government agency. It collected funds from the agency's affiliated or related enterprises, including state-owned and private enterprises and thus had no interest in soliciting.

Collecting contributions from affiliated organizations blurred the boundary between involuntary and voluntary donations. Moreover, as the public was unable to distinguish government-related nonprofits from independent nonprofits, there was widespread public disdain and distrust of all types of charitable 
solicitation, making it more difficult for independent nonprofits to seek voluntary donations.

Second, nonpublic fundraising foundations, being kept away from solicitation, were restricted to relying on contributions from their founding members and specific donors who were reached by "private" and "personal" means, in contrast to solicitation by "public" and "non-personal" means. However, the difficulty in clearly defining the difference between private and public solicitations gave rise to uncertainty and confusion in the charitable fundraising market.

Third, there were controversies on whether shetuans and minfeis were misdirected in the new policies. Some interviewees pointed out that a large proportion of minfeis was actually for-profit enterprises, such as training schools, hospitals, and day care centers, and should not enjoy tax-exempt benefits. Similarly, the majority of shetuans served as the representatives of the government in industries or interest groups such as business associations, professional associations, and women associations. Therefore they depended primarily on special government grants and had little incentive for solicitation.

Some nonprofit leaders we interviewed expressed their fear that the discretionary and unreasonable authorization system in the new policies could damage the public's trust of the entire nonprofit sector. Out of this concern, they called for a restructuring of the system in which as the first step, government agencies and government-sponsored nonprofits should be separated from other nonprofits in order to build a fair and equitable institutional environment for nonprofit fundraising.

Nonprofits' Weak Fundraising Capacity. The nonprofit sector as a whole was not yet well prepared for the newly acquired solicitation rights, as a result of which many nonprofits were not enthusiastic about fundraising. Organizing a successful fundraising event usually would require supportive constituencies, capable work teams, sophisticated skills, and financial resources. Lack of them (or any of them) would restrain an eligible but incapable nonprofit from succeeding on the fundraising market, as we explain in detail below.

First, most nonprofits were too young to develop a broad range of constituencies who usually serve as the pool of donors. Among the 30 nonprofits being interviewed, the oldest had a history of 20 years, and 14 of them were founded after 2010.

Second, most nonprofits were too small (in terms of employment size) and also financially too weak to organize effective fundraising events. Among the 30 nonprofit organizations interviewed, four had more than 20 full-time employees, eight had 10-19 full-time employees, eight had 6-10 full-time employees, and the remaining 10 had less than 5 full-time employees. In terms of expenditure, seven nonprofits had their annual spending above RMB 10 million, six between 
RMB 5-10 million, nine between RMB 1-5 million, three between RMB 500,000 and 1 million, and five less than RMB 500,000. With such small sizes of staff and annual spending, most nonprofits were simply unable to organize major fundraising events.

Third, most nonprofits had not developed special organizational structures for fundraising. Among the 30 nonprofit organizations, only nine established a fundraising committee at the board of directors, and 13 had special employees in charge of fundraising. Apparently, the lack of organizational preparedness would prevent the organization from participating in fundraising events.

It appears that nonprofit leaders were aware of the inadequacy in their preparation. One of our interviewees commented,

There are two reasons why grassroots nonprofit organizations are not enthusiastic about fundraising. First, soliciting contributions from the public requires high promotion capacity and costs heavily. Grassroots nonprofits are neither capable nor able to pay the cost. Second, grassroots nonprofits lack fundraising experience and don't know how to plan for fundraising events.

Inadequate capacity also hindered foundations who were usually more capable than other nonprofits. The CEO of a public fundraising foundation said,

Most public fundraising foundations in Shanghai did not fundraise owing to the high expenses of organizing major fundraising events. Two major exceptions are the CCF and Foundation X [a public fundraising foundation independent from the government]. The CCF performed fundraising campaigns not so much to collect contributions as to promote itself among the public. Foundation X was relatively successful in fundraising.

\section{Discussion \& Conclusions}

In this study, we draw upon archival data and field work to compare the new fundraising policies from two local jurisdictions - Shanghai and Guangzhou - and examine the reactions of nonprofits toward these policies. We find qualitative differences between the policy changes in the two cities. Despite the differences, the policy reforms from both cities represented a useful step toward a more supportive regulatory environment for Chinese nonprofits. Yet somewhat surprisingly, our findings also show that local nonprofits were not unanimously excited about the solicitation eligibility that had long been deprived of by the state. Only a small fraction of nonprofit organizations fundraised under the new policies and their performance varied remarkably. In particular, nonprofits displayed three types of attitudes toward the new policies that loosened fundraising regulation: welcome, 
indifference, and challenge. Our further analysis reveals that fragmented policies on nonprofit registration and taxation, discretionary authorization system, and nonprofit organizations' weak fundraising capacity together shaped nonprofits' responses to the policy initiatives.

Our study makes several important contributions to nonprofit policy research. First, our findings suggest that only loosening eligibility regulation does not necessarily increase nonprofit organizations' participation in solicitation, which is closely correlated with other institutional factors such as registration, tax exemption, government granting, and cross-departmental and cross-jurisdictional coordination within the government system. Without a well-integrated policy and law system to coordinate different institutional factors, a single policy initiative cannot work well even with a capable government. ${ }^{13}$

Second, our research implies that nonprofit organizations' capacity and their relationship with the government shape their responses to a policy initiative. As observed in both cities, unregistered nonprofits and ineligible yet capable nonprofits were inclined to distrust and challenge the policy, eligible but incapable nonprofits tended to ignore the policy, and eligible and capable nonprofits would welcome the policy. These findings deserve some further examination. Future policy studies should explore how the institutional environment and nonprofit-specific factors shape nonprofit organizations' fundraising engagement and how the environmental and organizational factors interplay with each other. Studies along this direction will contribute to policy improvement on charitable solicitation by developing better incentive mechanisms based on nonprofits' capability, need, and eligibility.

Finally, from the perspective of policy development, our research suggests that nonprofit policies and nonprofit organizations' responses may influence each other in the process of implementing a policy initiative. China's current nonprofit regulatory system has been embedded in a state-civil-society relationship which features the state's restriction of and domination over the civil society. The existence of numerous government-affiliated nonprofits embodied the state's political will (see Kang and Han 2005), which in turn gave rise to policy fragmentation and nonprofit organizations' distrust. However, policy initiatives can also change nonprofits' attitudes and shape the public's engagement. For example, independent nonprofits' success in obtaining voluntary donations may prompt government-affiliated nonprofits, who otherwise would depend solely on involuntary contributions from government-related donors, to

13 As commented in previous text, the new Charity Law has made significant progress in terms of registration and fundraising regulation but had limited progress regarding tax deduction. In addition, how previous policies will be reconciled with the new law will depend greatly on specific implementation rules that are being developed by the government. 
sharpen their fundraising skills and improve their accountability. Also, given that many nonprofits have been playing in the grey zone between solicited and unsolicited contributions, policy makers need to develop amendments to the current fundraising policy that would define solicitation as clearly as possible, which has proved to be a challenge even in societies where nonprofits' fundraising rights are well protected by legislation (e. g. Liazos 2000).

Acknowledgement: An earlier version of the paper was presented at the annual conference of the Association for Research on Nonprofit Organizations and Voluntary Action (ARNOVA) in Chicago in November 2015. We thank the nonprofit leaders from Shanghai and Guangzhou who participated in our study. We also thank Constance Flanagan, Charlotte Ren, Yuanxia Sun, Mark Sidel, and the anonymous reviewers for their thoughtful comments and suggestions. This research is partially supported by a grant from the School of Human Ecology at the University of Wisconsin - Madison.

Funding: The Charles Stewart Mott Foundation is a major sponsor of Nonprofit Policy Forum, underwriting its open access to the public. Other sponsors include the Levin College at Cleveland State University and the Association for Research on Nonprofit Organizations and Voluntary Action. This special issue was funded through a grant by the Kresge Foundation to ARNOVA.

\section{Appendix: Characteristics of the $\mathbf{3 0}$ Nonprofit Organizations Interviewed in the Study}

\begin{tabular}{|c|c|c|c|c|c|c|c|c|}
\hline NPO & Location & Type & Work Areas & $\begin{array}{l}\text { Staff } \\
\text { Size }\end{array}$ & $\begin{array}{l}\text { Annual } \\
\text { Spending } \\
\text { (RMB 1,000) }\end{array}$ & $\begin{array}{l}\text { Fundraising } \\
\text { Revenues }^{a} \\
\text { (RMB } 1,000 \text { ) }\end{array}$ & $\begin{array}{l}\text { Fundraising } \\
\text { Committee }\end{array}$ & $\begin{array}{l}\text { Fundraising } \\
\text { employees }\end{array}$ \\
\hline No. 1 & Shanghai & minfei & $\begin{array}{l}\text { Youth } \\
\text { development }\end{array}$ & 12 & 3500 & 40 & No & 0 \\
\hline No. 2 & Shanghai & minfei & child education & 23 & 5130 & 30 & No & 3 \\
\hline No. 3 & Shanghai & minfei & $\begin{array}{l}\text { Community } \\
\text { development }\end{array}$ & 10 & 1600 & 0 & Yes & 2 \\
\hline No. 4 & Shanghai & minfei & $\begin{array}{l}\text { Legal service for } \\
\text { Nonprofit } \\
\text { organizations }\end{array}$ & 2 & 300 & 0 & No & 0 \\
\hline No. 5 & Shanghai & minfei & $\begin{array}{l}\text { Community } \\
\text { development and } \\
\text { NPO supporting }\end{array}$ & 185 & 53,000 & 0 & No & 0 \\
\hline No. 6 & Shanghai & $\begin{array}{l}\text { public } \\
\text { fundraising } \\
\text { foundation }\end{array}$ & Joint fundraising & 12 & 31,000 & About 9,000 & No & 3 \\
\hline
\end{tabular}


(continued)

\begin{tabular}{|c|c|c|c|c|c|c|c|c|}
\hline NPO & Location & Type & Work Areas & $\begin{array}{r}\text { Staff } \\
\text { Size }\end{array}$ & $\begin{array}{l}\text { Annual } \\
\text { Spending } \\
\text { (RMB 1,000) }\end{array}$ & $\begin{array}{l}\text { Fundraising } \\
\text { Revenues }^{\mathrm{a}} \\
\text { (RMB 1,000) }\end{array}$ & $\begin{array}{l}\text { Fundraising } \\
\text { Committee }\end{array}$ & $\begin{array}{l}\text { Fundraising } \\
\text { employees }\end{array}$ \\
\hline No. 7 & Shanghai & $\begin{array}{l}\text { public } \\
\text { fundraising } \\
\text { foundation }\end{array}$ & Child education & 42 & 57,000 & About 1,7000 & Yes & 10 \\
\hline No. 8 & Shanghai & shetuan & $\begin{array}{l}\text { Community } \\
\text { development }\end{array}$ & 3 & About 500 & 0 & No & 0 \\
\hline No. 9 & Shanghai & $\begin{array}{l}\text { public } \\
\text { fundraising } \\
\text { foundation }\end{array}$ & Multiple themes & 11 & 6,920 & About 5,000 & Yes & 3 \\
\hline No. 10 & Shanghai & $\operatorname{minfei}$ & NPO supporting & 16 & 6,000 & 0 & No & 0 \\
\hline No. 11 & Shanghai & shetuan & $\begin{array}{l}\text { Youth } \\
\text { development }\end{array}$ & 5 & 1,000 & 0 & No & 0 \\
\hline No. 12 & Shanghai & $\begin{array}{l}\text { Nonpublic } \\
\text { fundraising } \\
\text { foundation }\end{array}$ & $\begin{array}{l}\text { Aging service and } \\
\text { education }\end{array}$ & 11 & 13,000 & 0 & Yes & 2 \\
\hline No. 13 & Shanghai & $\begin{array}{l}\text { nonpublic } \\
\text { fundraising } \\
\text { foundation }\end{array}$ & Child education & 3 & 300 & 0 & No & 0 \\
\hline No. 14 & Shanghai & minfei & Aging service & 3 & About 700 & 0 & Yes & 1 \\
\hline No. 15 & Guangzhou & minfei & $\begin{array}{l}\text { Community service } \\
\text { and development }\end{array}$ & 268 & 24,000 & 0 & Yes & 5 \\
\hline No. 16 & Guangzhou & minfei & Children rights & 8 & 146,000 & 0 & No & 0 \\
\hline No. 17 & Guangzhou & minfei & $\begin{array}{l}\text { NPO capacity } \\
\text { building }\end{array}$ & 11 & About 2000 & 0 & No & 1 \\
\hline No. 18 & Guangzhou & $\operatorname{minfei}$ & $\begin{array}{l}\text { Community service } \\
\text { and development }\end{array}$ & 30 & 3,000 & 0 & No & 0 \\
\hline No. 19 & Guangzhou & minfei & $\begin{array}{l}\text { Children rights } \\
\text { and development }\end{array}$ & 7 & 1,470 & 300 & Yes & 0 \\
\hline No. 20 & Guangzhou & shetuan & Basic education & 12 & 16,740 & About 15,000 & Yes & 2 \\
\hline No. 21 & Guangzhou & $\begin{array}{l}\text { nonpublic } \\
\text { fundraising } \\
\text { foundation }\end{array}$ & $\begin{array}{l}\text { Community } \\
\text { development }\end{array}$ & 7 & 6,550 & 1,000 & Yes & 2 \\
\hline No. 22 & Guangzhou & $\begin{array}{l}\text { public } \\
\text { fundraising } \\
\text { foundation }\end{array}$ & $\begin{array}{l}\text { Youth } \\
\text { development }\end{array}$ & 7 & 30,000 & About 450 & No & 0 \\
\hline No. 23 & Guangzhou & unregistered & $\begin{array}{l}\text { Equality for } \\
\text { hepatitis patients }\end{array}$ & 2 & About 200 & About 80 & No & 0 \\
\hline No. 24 & Guangzhou & unregistered & LGBT rights & 4 & About 600 & 240 & No & 1 \\
\hline No. 25 & Guangzhou & unregistered & LGBT rights & 0 & 20 & 16 & No & 1 \\
\hline No. 26 & Guangzhou & $\begin{array}{l}\text { nonpublic } \\
\text { fundraising } \\
\text { foundation }\end{array}$ & $\begin{array}{l}\text { Women and } \\
\text { children rights }\end{array}$ & 8 & 3,300 & 60 & No & 2 \\
\hline No. 27 & Guangzhou & shetuan & Basic education & 2 & 1,050 & 0 & No & 0 \\
\hline No. 28 & Guangzhou & $\begin{array}{l}\text { nonpublic } \\
\text { fundraising } \\
\text { foundation }\end{array}$ & $\begin{array}{l}\text { Children } \\
\text { education }\end{array}$ & 4 & 8,900 & 0 & Yes & 1 \\
\hline No. 29 & Guangzhou & minfei & $\begin{array}{l}\text { Nonprofit capacity } \\
\text { building }\end{array}$ & 7 & 1,270 & 0 & Yes & 2 \\
\hline No. 30 & Guangzhou & minfei & Children rights & 6 & 600 & 10 & No & 0 \\
\hline
\end{tabular}

a We marked it as "0" if a nonprofit self-reported "not engaged in any fundraising events." It is worth noting that some nonprofits may count unsolicited donations into their fundraising revenues, and some others may not include unsolicited donations. 


\section{References}

Breen, O. B. 2009. "Regulating Charitable Solicitation Practices-the Search for a Hybrid Solution." Financial Accountability \& Management 25 (1):115-43.

Clark, J. 1995. "The State, Popular Participation, and the Voluntary Sector," World Development 23 (4):593-602.

Clarke, G. 1998. "Non-Governmental Organizations (NGOs) and Politics in the Developing World," Political Studies 46 (1):36-52.

Community Party of China. (November, 2013). "Decision of the Central Committee of the Communist Party of China on Some Major Issues." Accessed May 9, 2016. http://news.xinhuanet.com/politics/2013-11/15/c_118164235.htm.

Dirusso, A. A. 2011. "American NPO Law in Comparative Perspective." Washington University Global Studies Law Review 10:39.

Dong, B. 1950. Charitable and Social Welfare Causes in a New China [xinzhongguo de jiuji fuli shiye]. Accessed November 10, 2015. http://dangshi.people.com.cn/GB/144964/145605/ 237447/17008211.html.

Fisher, J. 1998. Nongovernments : NGOs and the Political Development of the Third World. Connecticut: Kumarian Press.

Guangzhou Congress. 2012. Guangzhoushi mujuan tiaoli [Guangzhou City Fundraising Regulations]. Accessed July 10, 2014. http://www.rd.gz.cn/page.do?pa= ff8080814501d8df014508bd0aa24456

Guo, C., J. Xu, D. H. Smith, and Z. Zhang. 2012. "Civil Society, Chinese Style: The Rise of the Nonprofit Sector in Post-Mao China." The Nonprofit Quarterly 19 (3):20-7.

Guo, C., and Z. Zhang. 2013. "Mapping the Representational Dimensions of Nonprofit Organizations in China." Public Administration 91 (2):325-46.

Hall, P. D. 2006. "A Historical Overview of Philanthropy, Voluntary Associations, and Nonprofit Organizations in the United States, 1600-2000." In The Nonprofit Sector: A Research Handbook, edited by W. W. Powell and R. Steinberg, 32-65. New Haven \& London: Yale University Press.

International Center for NPO Law. 2011. NGO laws in Sub-Saharan Africa. Accessed July 3, 2014. http://www.icnl.org/research/trends/trends3-3.pdf.

Johnson, P. D. 2011. "Global Institutional Philanthropy: A preliminary status report.

The Philanthropic Initiative.” Accessed July 3, 2014. http://www.cbd.int/financial/charity/ g-regionaloverview.pdf.

Kang, X. and H. Han. 2005. "The System of Differential Controls: A Study of the State-Society Relationship in Contemporary China." Sociological Research 6:73-89.

Lan, F. 2012. "Caogen NGO duannai [Grassroots NGOs Were Being Weaned], Xinshiji Magazine." Accessed October 2, 2015. http://magazine.caixin.com/2012-03-16/100369124.html.

Lee, R. 2009. “Modernizing Charity Law in China.” Pacific Rim Law \& Policy Journal 18:347-72.

Li, Q. 2014. "Guangzhou jiang jiangli shehui zuzhi xinxi gongshi zhidu [Guangzhou develops disclosure institutions for nonprofit organizations], Nanfang Ribao." November 6. Accessed October 10, 2015. http://www.chinanews.com/sh/2014/11-06/6757637.shtml.

Liazos, M. G. 2000. "Can States Impose Registration Requirements on Online Charitable Solicitors?” The University of Chicago Law Review 67 (4):1379-407. 
Jia, X. 2003. "The Status Quo of Civil Society and NGOs in China." In Development of Grassroots Democracy in China: 2012 [Zhongguo Jiceng Minzhu Fazhan Baogao: 2012), edited by Li Fan, 92-131. Northwest University Press.

Ministry of Civil Affairs. 2001. guanyu jinyibu kaizhan jingchangxing shehui juanzhu huodong de yijian [Ordinance of Promoting Regular Private Contributions]. Accessed October 5, 2015. http://www.china.com.cn/chinese/PI-c/67394.htm.

Ministry of Civil Affairs. (2015). shehui fuwu fazhan tongji: 2014 [Statistics of social service development in 2014]. Accessed May 15, 2016. http://www.mca.gov.cn/article/zwgk/ mzyw/201506/20150600832371.shtml.

NGOCN (2015). Unanswered questions in the draft law of philanthropy [cishanfa shishi xiaoguo shang liuzhe de wenhao]. Accessed November 10, 2015. http://www.chinadevelopment brief.org.cn/news-18087.htm.

Ogburn, M. M. 1989. "Regulation of Charitable Fundraising: Riley v. National Federation of the Blind of North Carolina, Inc." USFL Rev 24:205.

Payton, R. L. 1988. Philanthropy: Voluntary Action for the Public Good, p. 32 New York: American Council on Education.

Robbins, K. C. 2006. "The NPO Sector in Historical Perspective: Traditions of Philanthropy in the West." In The Nonprofit Sector: A Research Handbook, edited by W. W. Powell and R. Steinberg, 13-31. New Haven \& London: Yale University Press.

Shanghai Congress. 2012. Shanghaishi mujuan tiaoli [Shanghai Fundraising Regulations]. Accessed July 10, 2014. http://shzw.eastday.com/shzw/G/20120608/userobject1ai82190. html.

Simon, J., H. Dale, and L. Chisolm. 2006. "The Federal Tax Treatment of Charitable Organizations." In The Nonprofit Sector: A Research Handbook, edited by W. W. Powell and R. Steinberg, 267-306. New Haven \& London: Yale University Press.

Spires, A. J. 2011. "Organizational Homophily in International Grantmaking: US-Based Foundations and Their Grantees in China," Journal of Civil Society 7 (3):305-31.

Spires, A. J., L. Tao, and K. M. Chan. 2014. "Societal Support for China's Grass-Roots NGOs: Evidence From Yunnan, Guangdong and Beijing." China Journal 71:65-90.

Strauss, A., and J. Corbin. 1990. "Basics of Qualitative Research.” Thousand Oaks, CA: Sage.

Xu, F. 2011. "Transparency, Trust, and Supervision: Nonprofit Organizations' Lessons From the Guo Meimei Event [Touming Xinren Yu Jiandu -You Guomeimei Shijian Kan Gongyi Zuzhi De Fazhan)." Theory Frontier [Chinese) 11:40-2.

Yu, K. 2006. "Zhongguo gongmin shehui: gainian, fenlei yu zhidu huanjing [Chinese civil society: Definition, typology, and institutional environment]." zhongguo shehui kexue 1:109-22.

Zhao, X. (2013). A Study of Government Contracting by Chinese Nonprofit organizations [woguo zhengfu xiang shehui zuzhi goumai gonggong fuwu yanjiu]. Institute of Economic System and Management. Accessed August 29, 2015. http://www.china-reform. org/?content_501.html. 